\title{
Differentials in health-related quality of life of employed and unemployed women with normal vaginal delivery
}

Anthonia U. Chinweuba1*, ljeoma L. Okoronkwo' ${ }^{1}$, Agnes N. Anarado1', Noreen E. Agbapuonwu², Ngozi P. Ogbonnaya ${ }^{1}$ and Chikaodili N. Ihudiebube-Splendor ${ }^{1}$

\begin{abstract}
Background: The combination of child care and domestic work demands on both housewives and the employed (hired) women may impact their health-related quality-of-life. There is paucity of studies to ascertain this. This study investigated the differences in health-related quality of life of employed and unemployed women with normal vaginal delivery and associated socio-demographic variables.

Methods: This longitudinal study was done from March, 2012 to June, 2013. Modified SF-36V2 ${ }^{\text {TM }}$ health-related quality of life questionnaire was administered to 234 newly delivered women drawn from six selected hospitals in Enugu, Southeast Nigeria at 6, 12 and 18 weeks postpartum. Respondents were reached for data collection through personal contacts initially at the hospitals of delivery, and subsequently by visits to their homes/workplaces or cell-phone calls. Women were asked to indicate how each of 36 items applied to them at each of the three times. Data collection lasted for six calendar months and 17 days (from September 3rd 2012 to 20th March, 2013).

Results: All the women had their best HrQoL at 12 weeks postpartum. Employed women reported lower health-related quality-of-life than the unemployed at the three time-points, the lowest mean score being at 18 weeks postpartum (Mean = 73.9). Multiple comparison of scores of the two groups using Tukey HSD Repeated Mean showed significant variation on the eight subscales of the health-related quality-of-life. Physical functioning ( $p=0.045)$, Physical role limitation $(p=0.000)$, bodily pain $(p=0.000)$, social functioning $(p=0.000)$ and general health $(p=0.000)$ were unequal guaranteeing type 1 error. Women with higher education and personal income reported higher health-related quality-oflife $(p<0.05)$. Employed women have more problems with physical health components and are more negatively affected by increasing age except those with higher education and personal income.

Conclusions: Increased responsibilities combined with increasing age and low socio-economic status reduce women's health-related quality-of-life post-partum. The traditionally accepted paid 3 months maternity leave should be elongated by extra months to help women balance their daily work with baby care. Gender sensitive employment opportunities in favour of women are necessary to empower more women economically.
\end{abstract}

Keywords: Child care, Education, Employment, Normal vaginal delivery, Postpartum women, Quality of life

\footnotetext{
* Correspondence: anthonia.chinweuba@unn.edu.ng

${ }^{1}$ University of Nigeria, Nsukka, Enugu State, Nigeria

Full list of author information is available at the end of the article
}

(c) The Author(s). 2018 Open Access This article is distributed under the terms of the Creative Commons Attribution 4.0 International License (http://creativecommons.org/licenses/by/4.0/, which permits unrestricted use, distribution, and reproduction in any medium, provided you give appropriate credit to the original author(s) and the source, provide a link to the Creative Commons license, and indicate if changes were made. The Creative Commons Public Domain Dedication waiver (http://creativecommons.org/publicdomain/zero/1.0/) applies to the data made available in this article, unless otherwise stated. 


\section{Background}

The combination of child care and domestic work demands may impact their health-related quality-of-life (HrQoL) of housewives and the employed (hired) women. HrQoL is self-report of one's perceived feeling of comfort, ability to realize his/her life potentials and satisfaction with life as expressed in the person's physical, emotional and social functions of life. This study is a self-report, based on scores obtained on the eight subscales and single items of modified Short Form 36 version $2\left(\mathrm{SF} 36 \mathrm{v} 2^{\mathrm{mix}}\right) \mathrm{HrQoL}$ instrument by Ware and Sherbourne [1] that includes general health, physical functioning, physical role limitation, emotional role limitation, social functioning, bodily pains, vitality, and mental health of employed and unemployed women. Most available literatures on $\mathrm{HrQoL}$ view it as a framework for examining disease and its impact on a patient [1-4]. However, other life situations than disease, such as child birth and care, have been noted to impact on ones HrQoL.The few available studies that compare QoL in newly delivered women with paid job and the unemployed show that the later are often financially dependent and as a result experience more economic hardship than the former [5]. Meanwhile, based on Udo's [6] report, as at first quarter of 2016, only about $63.8 \%$ of Nigerian women were employed $-14 \%$ were unemployed while $22.2 \%$ were underemployed.

Age was shown by some studies as a strong factor influencing [7-11]. Regidor et al. [11] observes that persons aged 25-44 years had better mental health and general health while those aged 45-64 years had better physical functioning and general health. However, In contrast, Bolton et al. [8] observed that younger adults had higher HrQoL with physical activity than their older counterparts. Socio-economic status (SES) studies showed consistently high HrQoL for the most affluent and the most highly educated subjects, the contrary for the middle and lower income and education groups $[12,13]$. A multicentre cross-sectional observational study on SES and HrQoL of 4574 patients with chronic obstructive pulmonary disease by Meravitlles et al. [14] showed similar result.

The purpose of this study is to establish the differences in the eight sub-scales of HrQoL of employed and unemployed women at 6,12 and 18 weeks postpartum and to determine personal factors of age, education, and personal income (amount of money the woman had direct access to and control of - earned from employer (for employed women) or received as monthly stipend from spouse (for the unemployed)) that influence them, where they exist. This study hypothesized that: there is no difference in the HrQoL of employed and unemployed women following their return to routine tasks along with baby care at 12 and 18 weeks after normal delivery; there is no significant difference in HrQoL scores of employed and unemployed women at 18 weeks postpartum based on their age, education, and personal income. The study is expected to yield selfperception data source for establishing the QoL of postpartum mothers in this part of the world where women are exposed to a lot of socio-economic challenges $[15,16]$. Findings may be used as basis for making pertinent recommendations for health policies and legislation on interventions to improve situations of the vulnerable groups and guide the development of strategic plans for health and employment.

\section{Methods}

Design

This was a longitudinal, prospective descriptive study design as consenting newly delivered mothers were assessed without any intervention to determine their HrQoL changes at three points as they returned to prepregnancy daily activities.

\section{Setting}

The study was carried out in three local government areas in Enugu capital territory, f Enugu State, southeastern Nigeria from March, 2012 to June, 2013. Enugu is a city with an area of about $100 \mathrm{~km}$ [2]. It encompasses major high density residential and commercial areas in the urban part of Enugu State with a population of up to 100,000 residents [17] and ten residential layouts. Igbo language is the people's vernacular, However, as an urban community, English Language, which is Nigeria's official language, is spoken and understood by most of the people.

Located in the city are numerous private and public hospitals that function as peripheral and/or referral centres for maternal, newborn and child healthcare services.

\section{Population of the study}

The average monthly registration for 6 weeks post-natal visit in six selected hospitals popular in obstetric health services in Enugu was used to estimate the population of 363 newly delivered women used for the study.

\section{Sample}

Power analysis was used to estimate the sample size of 234 newly delivered mothers. Using the Creative Research Systems survey software of the Sample size calculator formula of: $s \mathrm{~s}=\left(\mathrm{Z}[2]^{*}(\mathrm{p}) *(1-\mathrm{p})\right) / \mathrm{C}$ [2]; where: $\mathrm{Z}=1.96, \mathrm{p}=$ proportion of target population (estimated to have complicationfree normal vaginal delivery) (expressed as 0.5$), \mathrm{C}=\mathrm{Confi}-$ dence Interval $(.04 \pm 4)$ [18], a sample of 187 was initially estimated. Applying the adjusted sample size formula for anticipated 20\% attrition rate: $\mathrm{q}=\mathrm{n} / 1-\mathrm{f}$ (where $\mathrm{q}$ is adjusted sample size; $\mathrm{n}$ is original sample size; and, $\mathrm{f}$ is estimated 
non-response rate) [19], the initial sample size estimate was adjusted from 187 to 234.. This sample size represented about $64.5 \%$ of the population.

Multi-stage sampling technique was adopted in the process of selecting the sampling units. Firstly, the city was stratified using its three Local Government Areas (LGAs). Then, two health facilities from each LGA commonly used by child bearing women were purposively selected (a total of 6 health facilities). The sample units to be recruited were proportionately predetermined to be $50 \%$ (117) employed and unemployed women, respectively.

The women that met the following inclusion criteria were recruited into the study: women aged between 20 and 44 years; had normal delivery of a healthy term baby in any of the selected hospitals within the past 6 weeks at the time of selection; either on a paid job outside home or an unpaid housewife; without history of complicated pregnancy/medical conditions; no stressinducing experiences (such as loss of a family member, divorce, or family problems); and, women who consent to participate. Consent of spouses of women who opted to be visited at home for the second and third rounds of data collection at 12 and 18 weeks post delivery respectively, were obtained to allow researcher to visit their matrimonial home.

\section{Instrument}

Modified form of the standardized Iranian version of Short-Form 36-item Version 2 Health Survey Questionnaire $\left(\mathrm{SF}-36 \mathrm{v} 2^{\mathrm{mw}}\right)$ was used for data collection in this study. The SF-36v2 $2^{\mathrm{mi}}$ is a standardized popular generic short form of HrQoL survey instrument developed by Ware and Sherbourne in 1996 with 36-item self-rated health status profile [20-24]. Iranian version of the SF-36 $2^{\text {ma }}$ is also standardized [22]. It measures eight health-related concepts: physical functioning (limitations in typical daily physical activities due to health problems), physical role limitation (limitations with work or other regular daily activities due to physical health problems), bodily pain, general health perceptions (self-rated health), vitality, social functioning (limitations in social activities with the family, friends, neighbours, or groups such as visits, meetings, wedding and burial ceremonies), emotional role limitation (limitations with work or other regular daily activities as a result of any emotional problems, such as feeling depressed or anxious), and perceived mental health (how the woman feels and how things have been with her). Psychometrically, these eight scales are hypothesized to form two distinct higher-order clusters - physical health component summary (PCS) and mental health component summary (MCS) - since they have certain physical and mental health variance in common. Thus, the taxonomy of items and concepts underlying the construction of the SF-36 scales and summary measures are at three levels, namely: 36 items; eight sub-scales that aggregate 2-10 items each; and, two summary measures that aggregate sub-scales.

The instrument is validated to be a self-completed or as interviewer-administered questionnaire in English Language under the name of SF-36v2 $2^{\mathrm{m} 1}$. Montazeri et al. [22] did a translation and validation study of the Iranian version of this SF-36v2 $2^{\mathrm{ma}}$. The SF-36v2 $2^{\mathrm{mat}}$ has been used worldwide in many studies $[1,4,13,22,25,26]$ and the Iranian version was recorded to have a well documented validity [22]. Both MCS and PCS of this Iranian version were shown to have satisfactory internal consistency reliabilities. Cronbach's alpha coefficient for the PCS was 0.87 and 0.82 for the MCS.

The English version of the instrument was used as this is the common language understood and spoken by all members of the study group. However, for clarity and better understanding of terms by respondents in the study area, some language modifications were made in some items of the original standardized Iranian version $\mathrm{SF}-36 \mathrm{v} 2^{\mathrm{m}}$ as attached [see Additional file 1]. Also, 3-item questionnaire was used to collect data on respondents' demographic information on age, educational level, and personal income per month. Education was based on highest educational qualification attained. For the purposes of reporting HrQoL by personal income, women were categorised into four groups based initially on Nigeria's minimum wage of N18,000.00 (US\$107) per month for government-employed workers and subsequently, by equivalent personal income (in equivalent sizes of N50,000.00 (US\$298) per month (between groups). For every woman recruited for possible inclusion, personal data including full name, popular (or preferred) name, home address, office address (where applicable), phone number (where available), and preferred contact mode (visit at home or office) were documented.

The researcher-modified instrument was validated for context and content by presenting a draft of it and a copy of the original instrument, as well as the research objectives, and scope to a professor in Measurement and Evaluation to comment on the appropriateness of arrangements and the modifications. To ascertain its reliability, 20 copies were administered to 20 postnatal women with similar characteristics that attended a specialist maternity hospital in another state in eastern Nigeria. The percentage scores of responses for each section of the instrument were subjected to split-half reliability test using Pearson's Product Moment Correlation. The alpha coefficient result of 0.87 was considered satisfactory.

\section{Data collection}

First contact with the women was when they visited health facility for 6 weeks postpartum care. Following selfintroduction of researcher (or assistant) and establishment 
of rapport, purpose of the study and need for repeat visits were explained, while necessary history and consent to participate were sought. Upon accepting to participate, and after signing the informed consent sheet, those who met the inclusion criteria had a copy of the instrument administered to them. They were asked to read the contents as carefully as possible and respond to each item as it applied to them. For those who could not read and/or write (due to their low level of education), the researcher or assistant helped by reading out the contents to the respondents and filling in the responses as objectively as possible. After 6 weeks, the researcher and/or assistant visited each respondent at the preferred contact place for second round data collection. For those who preferred interview through phone call, data were collected through cell phone discussion guided strictly by contents of the instrument. At the third round, data collection was repeated after another 6 weeks through the respondent-preferred means. Employed women who could not resume work when due (after 12 weeks), for any reason, were removed from the study. Data collection lasted for six calendar months and 17 days (from September 3rd 2012 to 20th March, 2013).

\section{Method of data analysis}

Data were analysed descriptively using frequency, percentages, mean and standard deviation (SD). For each scale of the SF-36v2 $2^{\text {ma }}$ the mean was computed and scores converted to percentages to ensure true proportion of values. The scores at 6,12 and 18 weeks were subjected to chi square test to determine the differences in dimensions of HrQoL for the employed and unemployed. Tukey test was used to compare the mean of the women's HrQoL scores at 6, 12 and 18 weeks postpartum while the data were subjected to analysis of variance (ANOVA) to determine the interaction between the two groups of women and their demographic variables of age, educational level and personal income at 6 , 12 and 18 weeks postpartum. All statistical analyses were performed using the IBM SPSS statistical software package version 23. All values of $p<0.05$ were considered significant.

\section{Results}

Of the 234 women enrolled at baseline, 23 (9.8\%) (10 unemployed and 13 employed women) were lost due to voluntary withdrawal, incorrect address/phone number, loss of baby, or failure to resume work at 12 weeks post delivery. Three unemployed women were deliberately withdrawn to equalize number with employed women. Final sample was 208 women (104 employed and 104 unemployed women), $88.9 \%$ of the baseline sample [see Additional file 2: Figure 1].

Table 1 showed the mean $( \pm \mathrm{SD})$ age of participants as $27.91( \pm 5.89)$ years, comprising mainly women within the age range of $20-24$ years $(36.0 \%)$ and $25-29$ years $(30.8 \%)$ respectively. While all the women, except 2 unemployed, had some form of formal education, more of the employed women $(53=51.0 \%)$ than the unemployed $(16=15.4 \%)$ had a tertiary education. The mean personal income per month for the participants was N48,159.00. The unemployed earned average of $\mathrm{N} 27,087.00$, while the employed earned higher (N69,231.00). Twenty-one out of 33 women that earned above N100,000.00 were employed. Conversely, 48 out of 52 women that earned less than N18,000.00 (Nigeria minimum wage standard) were unemployed.

Table 1 Characteristics of the respondents

\begin{tabular}{|c|c|c|c|c|c|c|c|}
\hline & & Tota & & Une & & $\mathrm{Em}$ & \\
\hline & & $\bar{F}$ & $\%$ & $\bar{F}$ & $\%$ & $\bar{F}$ & $\%$ \\
\hline Age & $20-24$ & 75 & 36.0 & 43 & 41.3 & 32 & 30.8 \\
\hline & $25-29$ & 64 & 30.8 & 34 & 32.7 & 30 & 28.8 \\
\hline & $30-34$ & 37 & 17.8 & 18 & 17.3 & 19 & 18.3 \\
\hline & $35-39$ & 21 & 10.1 & 8 & 7.7 & 13 & 12.5 \\
\hline & $40-44$ & 11 & 5.3 & 1 & 1.0 & 10 & 9.6 \\
\hline & Mean(SD) & 27.9 & & 26.7 & & 29. & \\
\hline Education & No formal & 2 & 1.0 & 2 & 1.9 & 0 & 0 \\
\hline & Primary & 24 & 11.5 & 21 & 20.2 & 3 & 2.9 \\
\hline & Secondary & 113 & 54.3 & 65 & 62.5 & 48 & 46.1 \\
\hline & Higher (Tertiary) & 69 & 33.2 & 16 & 15.4 & 53 & 51.0 \\
\hline Personal income & Less than $\mathrm{N} 18,000$ & 52 & 25.0 & 48 & 46.15 & 4 & 3.8 \\
\hline & N18.000- N50,000 & 95 & 45.7 & 48 & 46.15 & 47 & 45.2 \\
\hline & N51,000-N100,000 & 38 & 18.3 & 6 & 5.8 & 32 & 30.8 \\
\hline & $>\mathrm{N} 100,000$ & 23 & 11.0 & 2 & 1.9 & 21 & 20.2 \\
\hline & Mean & N48 & & N27 & & N6s & \\
\hline
\end{tabular}


Repeated measures ANOVA of scores on the eight subscale showed that both groups of women had their best HrQoL at 12 weeks postpartum. In all the subscales, the employed women reported lower HrQoL at the three time-points than the unemployed, the poorest being at 18 weeks postpartum (Mean $=73.9)$. At 18 weeks, the employed women reported more bodily pain, poorer physical role functioning and poorer social functioning (Mean scores: 51.0; 51.2; 52.9 respectively) than the unemployed (mean scores: 84.5; 88.3; 88.4 respectively). There were significant mean score differences between the unemployed and the employed women in the HrQoL subscales of physical functioning $(p=0.045)$, physical role limitation $(p=0.000)$, bodily pain $(\mathrm{p}=0.000)$, general health $(\mathrm{p}=0.000)$, and Social functioning $(\mathrm{p}=0.000)$ over time. (Table 2$)$.

Result of multiple comparison of scores of the employed and unemployed women in different age groups using Tukey HSD Repeated Mean showed that the eight subscales of the HrQoL varied significantly. However, physical role limitation, bodily pain and social functioning were unequal guaranteeing type 1 error. Young women (aged 20-25 years), however, had the lowest scores on mental health (Table 3).

The mean scores of the employed and unemployed women in different age group categories when compared using ANOVA showed that the mean score differences in the eight subscales of the HrQoL within the population sampled were highly significant $(p<0.05)$ at $95 \%$ confidence interval. Table 4.

Multiple comparisons of the mean scores of the employed and unemployed women in categories of educational groups using Tukey HSD Repeated Mean test (Table 5.) showed that the variance in the eight sub scales of the HrQoL were significant. The variations were less for vitality, social functioning and mental health but were unequal guaranteeing type 1 error.

Table 2 ANOVA of scores on eight subscales of HrQoL for the employed and unemployed women at 6, 12 and 18 weeks using Tukey Test

\begin{tabular}{|c|c|c|c|c|c|c|c|c|}
\hline \multirow[t]{2}{*}{ HrQoL Subscale } & \multirow[b]{2}{*}{ Time } & \multicolumn{2}{|c|}{ Mean } & \multirow[t]{2}{*}{ Std. Error } & \multirow[t]{2}{*}{ Sum of Squares } & \multirow[t]{2}{*}{$\mathrm{F}$} & \multirow[t]{2}{*}{ Sig. } & \multirow[t]{2}{*}{ Univariate Tests Siq } \\
\hline & & U & $E$ & & & & & \\
\hline \multirow[t]{3}{*}{ Physical functioning } & 6 wks & 93.5 & 92.3 & .950 & 2621.520 & 18.024 & .000 & .045 \\
\hline & 12 wks & 98.2 & 96.0 & .839 & 786.950 & 5.010 & .001 & \\
\hline & 18 wks & 95.8 & 93.9 & .937 & 974.729 & 5.811 & .000 & \\
\hline \multirow[t]{3}{*}{ Physical role limitation } & 6 wks & 80.6 & 75.2 & .697 & 428.260 & 3.500 & .009 & .000 \\
\hline & 12 wks & 93.1 & 90.2 & .918 & 1001.184 & 6.571 & .000 & \\
\hline & 18 wks & 88.3 & 51.2 & 1.186 & 5743.328 & 3.690 & .006 & \\
\hline \multirow[t]{3}{*}{ Bodily pain } & 6 wks & 81.5 & 80.1 & 1.287 & 512.099 & 1.238 & .296 & .000 \\
\hline & 12 wks & 85.5 & 89.6 & 1.618 & 3925.263 & 7.689 & .000 & \\
\hline & 18 wks & 84.5 & 51.0 & 1.085 & 4297.025 & 3.412 & .010 & \\
\hline \multirow[t]{3}{*}{ General health } & 6 wks & 91.6 & 86.7 & .932 & 804.184 & 4.109 & .003 & .000 \\
\hline & 12 wks & 94.3 & 89.4 & .700 & 2445.029 & 26.413 & .000 & \\
\hline & 18 wks & 89.3 & 85.3 & 1.228 & 9117.891 & 46.166 & .000 & \\
\hline \multirow[t]{3}{*}{ Vitality } & 6 wks & 82.4 & 83.1 & 1.496 & 1691.671 & 3.722 & .006 & .816 \\
\hline & 12 wks & 93.2 & 88.9 & 1.123 & 7856.645 & 39.611 & .000 & \\
\hline & 18 wks & 85.0 & 87.6 & 1.267 & 2483.240 & 8.569 & .000 & \\
\hline \multirow[t]{3}{*}{ Social functioning } & 6 wks & 84.5 & 84.8 & 1.301 & 1626.616 & 5.442 & .000 & .000 \\
\hline & 12 wks & 88.4 & 86.8 & 1.339 & 4386.555 & 13.377 & .000 & \\
\hline & 18 wks & 88.4 & 52.9 & 1.087 & 4063.882 & 2.839 & .025 & \\
\hline \multirow[t]{3}{*}{ Emotional role limitation } & 6 wks & 81.7 & 80.5 & 1.515 & 1423.269 & 3.274 & .013 & .223 \\
\hline & 12 wks & 88.5 & 94.1 & 1.012 & 2421.128 & 11.992 & .000 & \\
\hline & 18 wks & 93.9 & 81.9 & .633 & 1847.427 & 9.648 & .000 & \\
\hline \multirow[t]{3}{*}{ Mental health } & 6 wks & 85.4 & 87.1 & 1.339 & 1949.560 & 6.054 & .000 & .590 \\
\hline & 12 wks & 88.6 & 88.2 & 1.270 & 3247.683 & 11.030 & .000 & \\
\hline & 18 wks & 87.0 & 87.5 & 1.260 & 1969.339 & 6.396 & .000 & \\
\hline
\end{tabular}


Table 3 Tukey HSD Repeated Mean comparison of the HrQoL subscales of the women based on their age groups

\begin{tabular}{|c|c|c|c|c|c|c|c|c|}
\hline \multirow[t]{2}{*}{ HrQoL subscale } & \multicolumn{5}{|l|}{ Age } & \multicolumn{3}{|l|}{ Sig } \\
\hline & $20-24$ yrs. (75) & $25-29$ yrs. (64) & 30-34 yrs. (37) & 35-39 yrs. (21) & 40-44 yrs. (11) & Time 1 & Time 2 & Time 3 \\
\hline Physical functioning & 95.10 & 95.10 & 94.14 & 93.62 & 91.32 & .182 & .776 & .094 \\
\hline Physical role limitation & 82.02 & 80.45 & 80.18 & 77.40 & 70.23 & 1.000 & .191 & - \\
\hline Bodily pain & 79.99 & 79.53 & 78.18 & 78.13 & 74.38 & .146 & - & - \\
\hline General health & 91.57 & 90.94 & 89.40 & 85.18 & 80.74 & 1.000 & 1.000 & .085 \\
\hline Vitality & 90.06 & 89.01 & 87.14 & 86.01 & 82.93 & .147 & .165 & .187 \\
\hline Social functioning & 84.42 & 82.63 & 79.29 & 78.79 & 73.65 & .086 & .087 & - \\
\hline Emotional role limitation & 88.96 & 86.86 & 86.43 & 84.07 & 81.47 & .102 & .066 & .119 \\
\hline Mental health & 90.69 & 89.76 & 89.14 & 84.77 & 83.78 & .976 & .068 & .883 \\
\hline
\end{tabular}

NB: Harmonic Mean Sample Size $=25.705$

The mean scores of the employed and unemployed women in different c educational levels when compared using ANOVA showed that the variance in the eight subscales of the HrQoL within the population sampled were highly significant $(p<0.05)$ at $95 \%$ confidence interval except for social functioning. Table 6.

The mean scores of the employed and unemployed women in different categories of personal when compared using Tukey HSD Repeated Mean test (Table 7) showed that the eight subscales of the HrQoL had significant variation. Unequal variations were noted for physical functioning, bodily pain vitality and mental health guaranteeing type 1 error.

The mean scores of the employed and unemployed women in different categories of personal income when compared using ANOVA showed that the variance in the eight subscales of the HrQoL within the population sampled were highly significant $(\mathrm{p}<0.05)$ at $95 \%$ confidence interval. Table 8.

\section{Discussion}

A major finding from this study was that quality-of-life of post-natal women was best at 12 weeks but dropped as they resumed work outside the home. This implies that newly delivered women had the best HrQoL within their maternity leave period. Women who return to work after 12 weeks maternity leave may find their job more challenging with additional task of baby care particularly women without significant social support for domestic tasks. This increased responsibility and workload will most likely affects their HrQoL trajectories negatively. This suggests the need for a domestic social support, longer period of maternity leave and reduced workload, particularly for the employed women.

Bodily pains and problems with physical health reported by the women 6 weeks after resumption of work were likely to negatively affect their job performance. Their social functions might also be compromised. The findings, thus, different from Greenberg's [5]. Conflict between the women's formal or informal jobs and domestic tasks may make routine tasks cumbersome to accomplish. Poor social functioning may lead to depression, withdrawal, loss of concentration and aggressive behaviours. Since increased task, and reduced physiological or psychological energy result in less activity tolerance, their productivity in workplace is also likely to reduce.

Increasing age coupled with increasing responsibility could reduce one's HrQoL. Findings from this study indicated that with increasing age, the women, especially

Table 4 ANOVA of respondents' mean scores on eight subscales of HrQoL at 6, 12 and 18 weeks based on the women's age groups

\begin{tabular}{|c|c|c|c|c|c|c|c|c|c|c|c|c|}
\hline \multirow[t]{2}{*}{ Age (years) } & \multicolumn{2}{|l|}{$20-24$} & \multicolumn{2}{|l|}{$25-29$} & \multicolumn{2}{|l|}{$30-34$} & \multicolumn{2}{|c|}{$35-39$} & \multicolumn{2}{|c|}{$40-44$} & \multirow[t]{2}{*}{$\mathrm{F}$} & \multirow[t]{2}{*}{ Sig } \\
\hline & $x(43)$ & Y 32) & $x(34)$ & $Y(30)$ & x (18) & y (19) & x (8) & y (13) & $\times(1)$ & $y(10)$ & & \\
\hline Physical functioning & 71.1 & 72.7 & 78.2 & 73.2 & 85.6 & 73.1 & 100 & 91.0 & 82.0 & 86.6 & 7.809 & .000 \\
\hline Physical role limitation & 62.9 & 67.2 & 75.3 & 51.8 & 93.3 & 47.1 & 98.7 & 74.6 & 70.0 & 31.0 & 7.388 & .000 \\
\hline Bodily pain & 58.2 & 42.6 & 73.3 & 55.8 & 72.8 & 47.1 & 86.9 & 54.6 & 55.0 & 29.5 & 14.786 & .000 \\
\hline General health & 73.9 & 63.3 & 75.5 & 72.0 & 84.4 & 80.4 & 97.9 & 79.7 & 83.3 & 77.7 & 29.314 & .000 \\
\hline Vitality & 74.4 & 64.1 & 73.8 & 82.6 & 80.0 & 81.0 & 96.2 & 79.2 & 90.0 & 85.0 & 8.413 & .000 \\
\hline Social functioning & 53.7 & 48.4 & 76.7 & 57.0 & 73.3 & 53.6 & 100 & 62.3 & 80.0 & 23.0 & 7.969 & .000 \\
\hline Emotional role limitation & 68.8 & 61.7 & 74.5 & 69.3 & 93.3 & 67.5 & 91.7 & 76.9 & 80.0 & 81.3 & 14.347 & .000 \\
\hline Mental health & 68.2 & 65.9 & 74.8 & 87.5 & 70.0 & 85.8 & 98.1 & 85.8 & 90.0 & 85.5 & 4.699 & .003 \\
\hline
\end{tabular}

NB: $x=$ Unemployed women; $y=$ Employed women

Degree of freedom for all subscales $=3$ 
Table 5 Tukey HSD Repeated Mean comparison of HrQoL subscales scores of the women based on their educational level

\begin{tabular}{|c|c|c|c|c|c|c|c|}
\hline \multirow[t]{2}{*}{ HrQoL subscales } & \multirow[t]{2}{*}{ No formal education (2) } & \multirow[t]{2}{*}{ Primary education (24) } & \multirow[t]{2}{*}{ Secondary education (113) } & \multirow[t]{2}{*}{ Higher education (69) } & \multicolumn{3}{|c|}{ Sig $(a=0.05)$} \\
\hline & & & & & $\begin{array}{l}\text { Time } \\
1\end{array}$ & $\begin{array}{l}\text { Time } \\
2\end{array}$ & $\begin{array}{l}\text { Time } \\
3\end{array}$ \\
\hline Physical functioning & 82.17 & 84.35 & 86.70 & 89.53 & .134 & - & - \\
\hline Physical role limitation & 82.67 & 81.71 & 82.03 & 78.96 & .839 & - & - \\
\hline Bodily pain & 74.67 & 76.88 & 80.54 & 76.49 & .569 & - & - \\
\hline General health & 88.50 & 89.86 & 90.83 & 87.09 & .242 & - & - \\
\hline Vitality & 86.83 & 80.31 & 87.13 & 88.34 & .066 & .947 & - \\
\hline Social functioning & 82.83 & 91.22 & 95.49 & 94.13 & 1.000 & .268 & - \\
\hline $\begin{array}{l}\text { Emotional role } \\
\text { limitation }\end{array}$ & 88.17 & 85.63 & 88.03 & 85.11 & .479 & - & - \\
\hline Mental health & 90.00 & 86.83 & 81.24 & 75.66 & .458 & .099 & - \\
\hline
\end{tabular}

NB: Harmonic Mean Sample Size $=7.080$

the employed, experienced more bodily pains, which may have affected their social functions and regular daily activities. This finding was consistent with those of Cohen [7]; Bolton [8], Bonsergent [9], and Al-Farsi [10]. The older women were likely to have a higher parity. This and similar social and cultural factors may mean increased responsibilities and increased demand for physical energy and social involvements. Unemployed and employed women aged 20-25 years had the lowest scores on mental health probably because being young the women are likely to be inexperienced mothers. Lack of experience can be a source of frustration and stress as the woman still undergoes some motherhood adaptation processes. It is not clear, however, why the unemployed women aged 25-35 years had poorer mental health than the employed women of the same age. Further studies are recommended for this.

The higher the women's educational level, the higher their reported HrQoL irrespective of their employment status. Highly educated women have increased chance of getting well-paid job which in turn increases their affordability and accessibility to quality living conditions - this is probably independent of their current employment status. This was in agreement with earlier studies such as Ross et al. [12] and Meravitlles et al. [14]. However, unemployed women with tertiary education had reduced scores on the subscales of general health, emotional role limitation and mental health when compared with their counterparts. It is possible therefore that high educational attainment without attendant practice reduces ones emotional and mental health. If this is so, then, it will most likely be prominent among women who become housewives not by their own volition but as a result of some external factors such as spouse disapproval. Being a housewife but restricted from formal work despite educational attainment may, therefore, affect the woman's psyche which may be manifested in poor physical and mental health.

HrQoL of the women increased with their personal income irrespective of time. High personal income increases access to comfort and enhances psycho-social wellbeing. This implies a better state of mind and body. Although more employed women (21) than the unemployed (2) that entered the study had monthly personal income above $\mathrm{N} 100,000.00$, it is significant to observe that women with higher personal income, whether unemployed or employed, had higher scores on the HrQoL

Table 6 ANOVA of respondents' mean of scores on eight subscales of HrQoL at 6, 12 and 18 weeks based on the women's educational level

\begin{tabular}{|c|c|c|c|c|c|c|c|c|c|c|}
\hline \multirow[t]{2}{*}{ Educational level } & \multicolumn{3}{|c|}{ Unemployed } & \multirow[b]{2}{*}{$H(16)$} & \multicolumn{4}{|c|}{ Employed } & \multirow[t]{2}{*}{$\mathrm{F}$} & \multirow[t]{2}{*}{ Sig } \\
\hline & $N(2)$ & $P(21)$ & $S(65)$ & & $\mathrm{N}(0)$ & $\mathrm{P}(3)$ & S (48) & $\mathrm{H}(53)$ & & \\
\hline Physical functioning & 60.1 & 75.4 & 85.5 & 92.7 & - & 61.9 & 86.3 & 95.5 & 11.080 & .000 \\
\hline Physical role limitation & 48.7 & 65.0 & 75.0 & 94.1 & - & 55.5 & 62.0 & 93.3 & 18.260 & .000 \\
\hline Bodily pain & 51.5 & 58.3 & 70.0 & 83.7 & - & 58.4 & 55.7 & 88.3 & 3.796 & .011 \\
\hline General health & 66.2 & 60.1 & 78.3 & 71.9 & - & 65.1 & 65.7 & 88.9 & 14.329 & .000 \\
\hline Vitality & 61.2 & 49.0 & 75.0 & 94.6 & - & 75.6 & 66.8 & 90.0 & 14.772 & .000 \\
\hline Social functioning & 68.8 & 59.5 & 70.0 & 90.9 & - & 57.5 & 51.4 & 91.6 & 2.013 & .113 \\
\hline Emotional role limitation & 58.3 & 65.5 & 80.0 & 74.6 & - & 57.0 & 75.0 & 88.9 & 8.406 & .000 \\
\hline Mental health & 59.7 & 54.0 & 77.5 & 73.0 & - & 71.7 & 53.6 & 95.8 & 5.309 & .002 \\
\hline
\end{tabular}

NB: $N$ No formal education, $P$ Primary, $S$ Secondary, $H$ Higher

Std Dev = Standard Deviation; Degree of freedom for all subscales $=3$ 
Table 7 Tukey HSD Repeated Mean comparison of HrQoL subscales scores of the women based on their personal income

\begin{tabular}{|c|c|c|c|c|c|c|c|}
\hline \multirow[t]{2}{*}{ HrQoL Subscales } & \multirow[t]{2}{*}{$<\mathrm{N} 18,000(52)$} & \multirow[t]{2}{*}{ N18,000-N50,000 (95) } & \multirow[t]{2}{*}{ N51,000-N100,000 (38) } & \multirow[t]{2}{*}{$>100,000(23)$} & \multicolumn{3}{|c|}{$\operatorname{Sig}(a=0.05)$} \\
\hline & & & & & Time 1 & Time 2 & Time 3 \\
\hline Physical functioning & 92.49 & 96.03 & 92.85 & 94.79 & .101 & .604 & - \\
\hline Physical role limitation & 86.89 & 80.17 & 75.91 & 71.56 & 1.000 & 1.000 & 1.000 \\
\hline Bodily pain & 81.16 & 79.44 & 75.70 & 75.15 & .110 & .801 & - \\
\hline General health & 90.83 & 90.72 & 88.52 & 82.67 & 1.000 & 1.000 & .999 \\
\hline Vitality & 84.57 & 87.00 & 89.69 & 85.67 & .191 & .122 & - \\
\hline Social functioning & 83.01 & 82.33 & 78.03 & 75.72 & .578 & .084 & .981 \\
\hline Emotional role limitation & 88.19 & 86.86 & 85.83 & 82.38 & 1.000 & .629 & .404 \\
\hline Mental health & 84.20 & 87.74 & 88.56 & 90.63 & .060 & .172 & - \\
\hline \multicolumn{3}{|c|}{ Harmonic Mean Sample Size } & 40.18 & & & & \\
\hline
\end{tabular}

scales. Studies such as Ross et al. [12] and Tucker [13] support this positive correlation of $\mathrm{HrQoL}$ with SES. The findings suggest SES as a measure of health and that employed women, particularly those with higher education that increases their chances of better placement on the job, had more satisfactory life. This is supported by Meravitles et al. [14] and Tucker et al. [13]. With evidence from the findings, the ability to have reasonable access to income is essentially a means to an improved HrQoL.

A major strength of this study is its prospective design and multiple time evaluation of the women's HrQol. which enabled the researchers to identify HrQol change overtime. As a limitation, the study was conducted in an urban area where most women had access to good quality living conditions. Rural dwellers live with higher level of poverty than urban dwellers. The findings therefore cannot be extended to employed and unemployed women in rural settings. The respondents were constrained by the scales; they did not have the opportunity to express other ideas outside of the items in the SF-36v2 ${ }^{\text {mat }}$. Further qualitative studies are indicated to elicit some socio-cultural factors and issues in postpartum HrQoL of Nigerian women.

\section{Conclusion}

The study revealed that newly delivered women's HrQoL is at its peak at 12 weeks postpartum and starts to decline as they go back to their routine full time job, especially for the employed women who reported more problems with physical health components. Employed women are more negatively affected by increasing age except those with higher education and personal income.

It is recommended that the traditionally accepted paid maternity leave of 3 months should be elongated by extra months to help the woman balance her daily work with baby care demands while she maintains a good HrQoL. However, further research is required to determine the best duration for maternity leave. Also, paternity leave should be granted to fathers, on request, so that they will have time at home to assist their spouse as may be necessary. Gender sensitive employment opportunities should be created to empower more women economically. Programmes should be designed to ensure that these at risk groups, that is women of child bearing age, earn at least the national minimum wage of N18,000.00 to enhance their economic status.

Table 8 ANOVA of respondents' mean scores on the eight subscales of HrQoL at 6, 12 and 18 weeks based on the women's personal income

\begin{tabular}{|c|c|c|c|c|c|c|c|c|c|c|}
\hline \multirow{2}{*}{$\begin{array}{l}\text { Personal income }(\mathrm{N}) / \\
\text { month }\end{array}$} & \multicolumn{2}{|c|}{$<\mathrm{N} 18,000$} & \multicolumn{2}{|c|}{$\mathrm{N} 18,000-\mathrm{N} 50,000$} & \multicolumn{2}{|c|}{$\mathrm{N} 51,000$-N100,000 } & \multicolumn{2}{|c|}{$>\mathrm{N} 100,000$} & \multirow[t]{2}{*}{$\mathrm{F}$} & \multirow[t]{2}{*}{ Sig } \\
\hline & $\times(48)$ & $y(4)$ & $\times(48)$ & y (47) & $x(6)$ & y (32) & $x(2)$ & $y(21)$ & & \\
\hline Physical functioning & 86.0 & 61.9 & 91 & 84.4 & 100 & 89.2 & 96.3 & 89.2 & 8.893 & .000 \\
\hline Physical role limitation & 67.5 & 54.7 & 80.0 & 44.4 & 100 & 60.8 & 92.5 & 60.8 & 38.275 & .000 \\
\hline Bodily pain & 82.5 & 60.2 & 66.7 & 40.9 & 88.7 & 66.2 & 91.2 & 66.2 & 4.607 & .004 \\
\hline General health & 81.7 & 78.3 & 83.3 & 83.3 & 95.2 & 83.3 & 94.1 & 83.3 & 42.578 & .000 \\
\hline Vitality & 60.0 & 69.5 & 83.3 & 82.2 & 97.5 & 85.7 & 72.0 & 85.7 & 6.850 & .000 \\
\hline Social functioning & 75.0 & 49.0 & 76.6 & 48.8 & 98.7 & 62.3 & 65.4 & 62.3 & 6.891 & .000 \\
\hline Emotional role limitation & 66.7 & 62.8 & 77.8 & 68.8 & 98.3 & 76.5 & 77.8 & 76.5 & 15.133 & .000 \\
\hline Mental health & 62.5 & 60.5 & 83.3 & 80.9 & 93.7 & 87.9 & 71.0 & 87.9 & 7.006 & .000 \\
\hline
\end{tabular}

NB: $x=$ Unemployed women; $y=$ Employed women; Std Dev. = Standard Deviation Degree of freedom for all subscales $=3$ 


\section{Additional files}

Additional file 1. Instrument modification: Details of modifications on specified items of the original standardized Iranian English version SF-36V2 ${ }^{\mathrm{TM}}$. (DOCX $\left.14 \mathrm{~KB}\right)$

Additional file 2: Figure 1. Flow chart indicating attrition of women from the study. (PPTX 43 KB)

Additional file 3. Instrument: Sample of instrument used to collect data on personal profile of respondents and the modified SF-36V2 ${ }^{\mathrm{TM}}$. (DOCX $34 \mathrm{~KB}$ )

\section{Abbreviations}

HrQoL: Health-related Quality of Life; LGA: Local Government Area; MCS: Mental Component Summary; PCS: Physical Component Summary;

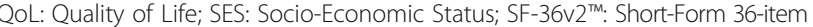
Version 2 Health Survey Questionnaire

\section{Acknowledgements}

We wish to thank all mothers who responded to our request to provide information for this study as well as their spouse who allowed us to visit their wife in their matrimonial home for second and third batches data collection. This enhanced complete data collection. We are also indebted to Prof. Obinna Onwujekwe of Faculty of Health Sciences and Technology, College of Medicine, University of Nigeria, Enugu Campus, for accepting to do contextual editing of the final draft of the work.

\section{Funding}

This study was not supported by any grant. The study design; data collection, analysis and interpretation of data; writing of the paper; and the decision to submit the paper for publication were, therefore, sole responsibility of the authors.

\section{Availability of data and materials}

All datasets that support the conclusions in this article are presented in the manuscript and additional files. However, to maintain confidentiality, all dataset relating to individual participants shall only be available on request and with approval of the participant [Additional file 3].

\section{Authors' contributions}

AUC prepared the study protocol, designed the study, drafted the manuscript, researched data and carried out the statistical analysis; ILO supervised the statistical analysis, contributed to the discussion and editing of the manuscript; ANA co-supervised and contributed in the discussion and acquisition of the data; NPO contributed to the discussion, supervised the statistical analysis and editing of the manuscript; NEA participated in drafting the manuscript as well as in the discussion. CNI participated in the acquisition of the data and contributed in the discussion. All authors have critically reviewed the manuscript for important intellectual content and approved the final manuscript.

\section{Ethics approval and consent to participate}

Ethical approval was obtained from the Research Ethical Committee of University of Nigeria Teaching Hospital, Ituku-Ozalla (Ref. No. UNTH/CSA/329/NOL.5). Administrative permit was obtained from management of the hospital before prospective respondent was approached. All participants were fully informed of the objectives and design of the study and written consents were received from the participants. Also, because the data were to be collected in the woman's matrimonial home in some situations, written consent of the spouse was collected on visit to their home as applicable.

\section{Consent for publication}

Not applicable.

\section{Competing interests}

This research work, or parts of it, has not been published elsewhere and it is not under consideration at any other journal. The authors declare that they have no competing interests with respect to the research, financial aid, authorship, and/or publication of this article.

\section{Publisher's Note}

Springer Nature remains neutral with regard to jurisdictional claims in published maps and institutional affiliations.

\section{Author details}

${ }^{1}$ University of Nigeria, Nsukka, Enugu State, Nigeria. ${ }^{2}$ Nnamdi Azikiwe

University, Awka, Anambra State, Nigeria.

Received: 9 January 2016 Accepted: 28 November 2017

Published online: 10 January 2018

\section{References}

1. Bell JA, daCosta DiBonaventura M, Witt EA, Ben-Joseph R, Reeve BB. (2016). Use of the SF-36v2 health survey as a screen for risk of major depressive disorder in a US population-based sample and subgroup with chronic pain. Medical Care. https://doi.org/10.1097/MLR.0000000000000617 Retrieved from https://uncch.pure.elsevier.com/en/publications/use-of-the-sf-36v2health-survey-as-a-screen-for-risk-of-major-de. on 6/8/2017.

2. Norimatsu T, Osaki M, Tomita M, Te Z, Abe Y, Honda S. Factors predicting health-related quality of life in knee osteoarthritis among communitydwelling women in Japan: the Hizen-Oshima study. Orthopedics. 2011;34(9): e535-40. https://doi.org/10.3928/01477447-20110714-04.

3. Plugge $E$, Douglas N, Fitzpatrick R. Changes in health-related quality of life following imprisonment in 92 women in England: a three month follow-up study. Int J Equity Health. 2011;10:21. https://doi.org/10.1186/1475-9276-10-21.

4. Garster NC, Palta M, Sweitzer NK, Kaplan RM, Fryback DG. Measuring healthrelated quality of life in population-based studies of coronary heart disease: comparing six generic indexes and a disease-specific proxy score. Qual Life Res. 2009;18(9):1239-1247. Retrieved from https://link.springer.com/article/10. 1007/s11136-009-9533-8 on 10/8/2017.

5. Greenberg M. Real housewives \& black swan: Too rich \& too thin? Psychology Today 2011; Retrieved from https://www.psychologytoday.com on Sept 252014.

6. Udo B. Nigeria's unemployment crisis worsens; rate jumps by 518,000 in 3 months - NBS. Premium Times. 2016, May 22. https://www. premiumtimesng.com/news/headlines/203891-nigerias-unemploymentcrisis-worsens-rate-jumps-518000-3-months-nbs.html.

7. Cohen A, Baker J, Arden Cl. Association between body mass index, physical activity, and health-related quality of life in Canadian adults. J Aging Phys Act. 2016;24(1):32-8. https://doi.org/10.1123/japa.2014-0169. Accessed 6/8/2017.

8. Bolton K, Kremer P, Rossthorn N, Moodie M, Gibbs L, Waters E, Swinburn B $\&$ de Silva A. The effect of gender and age on the association between weight status and health-related quality of life in Australian adolescents. BMC Public Health 2014; 14:898. https://doi.org/10.1186/1471-2458-14-898. Accessed 6 Aug 2017

9. Bonsergent E, Benie-Bi J, Baumann C, Agrinier N, Tessier S, Thilly N, Briancon $\mathrm{S}$. Effect of gender on the association between weight status and healthrelated quality of life in adolescents. BMC Public Health. 2012:12:997. https:// doi.org/10.1186/1471-2458-12-997 12:997. Accessed 6 Aug 2017.

10. Al-Farsi YM, Brooks DR, Werler MM, Cabral HJ, Al-Shafei MA, Wallenburg HC Effect of high parity on the occurrence of prediabetes: a cohort study. ACTA Obstet Gyn Scan. 2010;89(9):1182-1186. https://doi.org/10.3109/00016349. 2010.501854. Accessed 12 Dec 14.

11. Regidor E, Barrio G, de la Fuente L, Domingo A, Rodriguez C, Alonso J. Association between educational level and health related quality of life in Spanish adults. J Epidemiol Commun H. 1999;53(2):75-82. Retrieved from https://www.ncbi.nlm.nih.gov/pmc/articles/PMC1756832/ on Oct 192015.

12. Ross NA, Garner R, Bernier T, Feeny DH, Kaplan MS, McFarland B, et al. Trajectories of health-related quality of life by socio-economic status in a nationally representative Canadian cohort. J Epidemiol Commun H. 2010. https://doi.org/10.1136/jech.2010.115378. Accessed 24 Oct 2017.

13. Tucker JN, Grzywacz JG, Leng I, Clinch CR, Arcury TA. Return to work, economic hardship, and women's postpartum health. Women Health. 2010:50(7):618-638. https://doi.org/10.1080/03630242. Accessed 17 Dec 2013.

14. Meravitlles M, Naberan K, Cantoni J, Azpeitia A. Socio-economic status and health-related quality of life (HRQL) of patients with chronic obstructive pulmonary disease. Respiration. 2011;82(5):402-408. https://doi.org/10.1159/ 000328766 . Accessed 28 Feb 15.

15. Chukuezi C. Socio-cultural factors associated with maternal mortality in Nigeria. J Soc Sci. 2010;1(5):22-26. Retrieved from https://www.aensionline. com/rjss/rjss/2010/22-26.pdf. on 21/09/13

16. Fox JK, Halpern LF, Ryan JL, Lowe KA. Stressful life events and the tripartite model: relations to anxiety and depression in adolescent females. J Adolescence. 2010;33(1):43-54. https://doi.org/10.1016/J.ADOLESCENCE.2009. 05.009. Accessed 29 Dec 2013. 
17. Adinna EN, Enete IC, Okolie A. Assessment of urban heat island and possible adaptations in Enugu urban using landsat-ETM. J Geogr Reg Plann. 2009;2(2):30-36. Retrieved from https://www.medwelljournals.com/abstract/ ?doi=pjssci.2009.26.31 on 11/12/2014.

18. Creative Research Systems Sample size calculator (n.d.). Your complete systems survey software solution n.d. Retrieved from https://www. surveysystem.com/sscalc.htm on 17/9/2014.

19. ANGEL STAT 509. Design and Analysis of Clinical Trials. Lesson 6: Sample Size and Power n.d.. Retrieved from https://onlinecourses.science.psu.edu/ stat509/node/57 on 17/9/2014.

20. Najera-Zuloaga J, Lee DJ \& Arostegu I. SF36rec: Short Form-36 Health Survey recode In HRQoL: Health Related Quality of Life Analysis 2017. Retrieved from https://rdrr.io/cran/HRQoL/man/SF36rec.html on 10/8/2017.

21. Laucis NL, Hays RD, Bhattacharyya T. Scoring the SF-36 in Orthopaedics: a brief guide. J Bone Joint Surg Am. 2015 Oct. 97(19):1628-1634. https://doi. org/10.2106/JBJS.0.00030. https://www.ncbi.nlm.nih.gov/pmc/articles/ PMC5029523/.

22. Montazeri A, Vahdaninia M, Mousavi SJ, Asadi-Lari M, Omidvari S, Tavousi M. The 12-item medical outcomes study short form health survey version 2.0 (SF-12v2): A population-based validation study from Tehran, Iran. Health Qual Life Outcomes. 2011;9(12). https://doi.org/10.1186/1477-7525-9-12. Accessed 22/09/14.

23. Mullin PA, Lohr KN, Bresnahan BW, McNulty P. Applying cognitive design principles to formatting HRQOL instruments. Qual Life Res. 2000;9(1):13-27. https://citeseerx.ist.psu.edu/viewdoc/summary?doi=10.1.1.519.5055.

24. Ware JE. Jr. SF-36 Health Survey Update. Spine 2000, 25(24), 3130-3139. Lippincott Williams \& Wilkins, Inc. https://doi.org/10.1097/00007632200012150-00008.

25. Tan ML, Wee HL, Lee J, Ma S, Heng D,Tai, ES, \& Thumboo J. Association of anthropometric measures with SF-36V2 PCS and MCS in a multi-ethnic Asian population. Qual Life Res. 2013;22(4):801-810. https://doi.org/10.1007/ s11136-012-0193-8. Accessed 6 Aug 2017

26. Torkan B, Parsay S, Lamyian M, Kazemnejad A, Montazeri A. Post-natal quality of life in women after normal vaginal delivery and caesarean section. BMC Pregnancy Childbirth. 2009;9:4. https://doi.org/10.1186/1471-2393-9-4. Accessed 17 Dec 2013

\section{Submit your next manuscript to BioMed Central and we will help you at every step:}

- We accept pre-submission inquiries

- Our selector tool helps you to find the most relevant journal

- We provide round the clock customer support

- Convenient online submission

- Thorough peer review

- Inclusion in PubMed and all major indexing services

- Maximum visibility for your research

Submit your manuscript at www.biomedcentral.com/submit 